\title{
FLORA OF THE VELIKI LAGAN AND MALI LAGAN ISLETS (DUGI OTOK ISLAND, CROATIA)
}

\author{
Marija PandžA ${ }^{1}$ \& Milenko Milović ${ }^{2}$ \\ ${ }^{1}$ Murterski škoji Primary School, Put škole 8, HR-22243 Murter, Croatia \\ (E-mail: marija.pandza@si.t-com.hr) \\ ${ }^{2}$ Medical School, Ante Šupuk Street, HR-22000 Šibenik, Croatia \\ (E-mail: milenko.milovic@si.t-com.hr)
}

Pandža, M. \& Milović, M.: Flora of the Veliki Lagan and Mali Lagan islets (Dugi otok island, Croatia). Nat. Croat., Vol. 24, No. 2., 215-222, Zagreb, 2015.

The flora of the two islets, Veliki Lagan (surface area of $2.16 \mathrm{ha}$ ) and Mali Lagan (1.04 ha), located along the north-west coast of Dugi otok island, was researched for the first time in 2014. Altogether, there were 39 species and subspecies within 37 genera and 21 families.

There were 35 and 24 taxa on Veliki Lagan and Mali Lagan, respectively. Therophytes (43.59\%) and plants of the Mediterranean floral element (43.59\%) prevailed on both islets. This highlighted the Mediterranean character of the flora.

Key words: islets, vascular flora, diversity, halophytes, eastern Adriatic, NE Mediterranean

Pandža, M. \& Milović, M.: Flora otočića Velikog i Malog Lagana (Dugi otok, Hrvatska). Nat. Croat., Vol. 24, No. 2., 215-222, Zagreb, 2015.

Tijekom 2014. po prvi put je istraživana flora Velikog (2,16 ha) i Malog Lagana (1,04 ha), otočića smještenih uz sjeverozapadni dio Dugog otoka. Zabilježeno je ukupno 39 vrsta i podvrsta svrstanih u 37 rodova i 21 porodicu. Na Velikom Laganu pronađeno je 35, a na Malom Laganu 24 svojte. U flori istraživanih otočića prevladavaju terofiti (43,59\%) i biljke mediteranskog flornog elementa (43,59 \%) što ukazuje na mediteranski karakter flore.

Ključne riječi: otočići, vaskularna flora, raznolikost, halofiti, istočni Jadran, SI Mediteran

\section{INTRODUCTION}

The farthest North-Western part of the island of Dugi otok was declared to be an important landscape in 1967, along with two islets, Mali Lagan (surface area of 1.04 ha), Veliki Lagan (2.16 ha) and two reefs: Oključić (0.43 ha) and Baričevac (0.41 ha) reefs (Fig. 1).

During 2012 and 2013, floristic researches of Veli Rat and Verunić, as well as of Oključić and Baričevac reefs (PAndžA \& Milović, 2013) were carried out. The islets of Veliki and Mali Lagan are low in altitude (about $2 \mathrm{~m}$ above the sea level) so they are completely exposed to the influence of salt. During $20^{\text {th }}$ century, people grew beans and cereals (barley and rye) on these islets and during summer they were used to graze sheep on (Ljubo Mirković, pers. comm.). When anthropogenic influences disappeared, sea-gulls started to nest on both islets.

The goal of this research is to determine the diversity of the flora of two small islets: Mali Lagan and Veliki Lagan and to complete the list of vascular flora of the important landscape of Veli Rat within the boundaries of which the islets are located. 


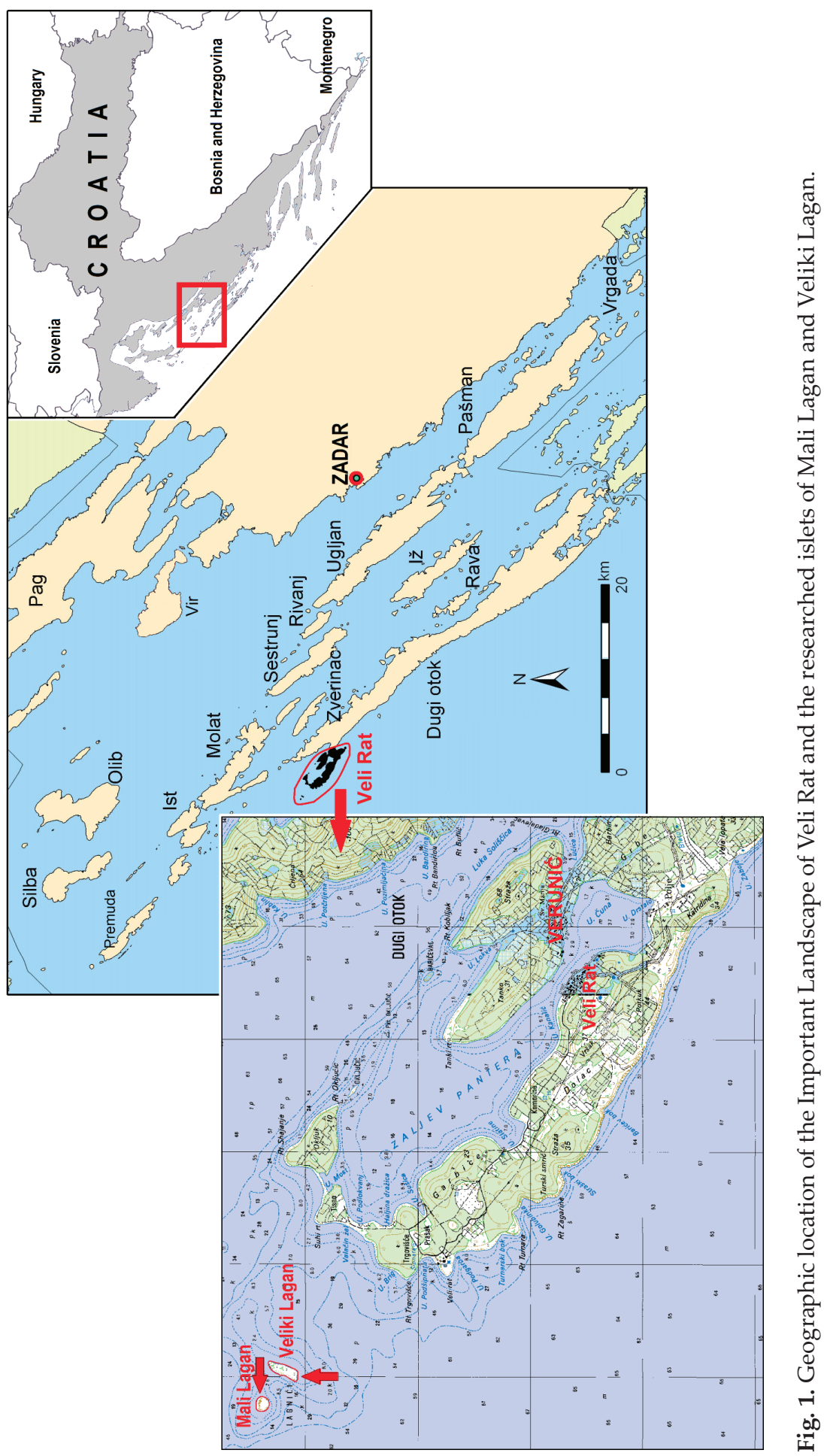




\section{MATERIAL AND METHODS}

The work was carried out during spring and summer 2014. Plant taxa determination was done using Pignatti (1982) and the nomenclature follows Nikolić (2014a).

In the list of flora, species and subspecies were listed in alphabetic order within higher taxonomic categories (genera, families, classes). Designations for islets, life form, chorological type (geoelement), threatened and protected status were provided for each taxon.

A numerical designation of the islet is provided as follows: 1 - Mali Lagan and 2 Veliki Lagan.

Life forms is determined according to system of RAUnKIAER (1934) and marked with the standard abbreviations: $\mathrm{P}-$ Phanerophytes, $\mathrm{Ch}-$ Chamaephytes, $\mathrm{H}$-Hemicryptophytes, G-Geophytes, T - Therophytes, Hy - Hydrophytes.

Geoelements are adjusted according to Horvatić (1963) and Horvatić et al. (1967/1968), and marked with the appropriate abbreviations in the flora list: MED - Mediterranean, SEU - South European, EURO - European, EUAS - Eurasian, CIHO - Circum-Holarctic and WISP - Widespread plants.

Species considered to be endemic according to NiкоLić et al. (2015) are denoted with the abbreviation "end" in the flora list. Taxa listed in the Red Book of Vascular Flora of Croatia (Nikolić \& Topić, 2005; Niкоlić, 2014b) are marked with its corresponding IUCN category: VU - Vulnerable and NT - Near Threatened.

Taxa protected by the Nature Protection Act (Anonymous, 2013a) and listed in the Ordinance on Designating Protected Taxa (Anonymous, 2013b) are denoted as "spr" strictly protected.

\section{RESULTS}

\section{List of species}

\section{SPERMATOPHYTA - ANGIOSPERMAE DICOTYLEDONES}

Amaranthaceae

Amaranthus retroflexus L.; 1; T; WISP

Apiaceae

Crithmum maritimum L.; 1, 2; Ch; MED

Asteraceae

Carduus micropterus (Borbás) Teyber ssp. micropterus; 2; H, MED; end

Inula crithmoides L.; 2; Ch; MED

Brassicaceae

Cakile maritima Scop.; 1, 2; T; WISP

Raphanus raphanistrum L. ssp. landra (Moretti ex DC.) Bonnier et Layens; 1, 2; T; WISP 
Caryophyllaceae

Silene vulgaris (Moench) Garcke ssp. angustifolia Hayek; 1, 2; H; SEU

Che nopodiaceae

Arthrocnemum macrostachyum (Moric) C.Koch; 1, 2; Ch; SEU

Atriplex littoralis L.; 1, 2; T; EUAS

A. prostrata Boucher ex DC in Lam. et DC.; 1, 2; T; WISP

Beta vulgaris L. ssp. maritima (L.) Arcang.; 1,2; H; MED

Chenopodium strictum Roth; 1,2; T; WISP

Ch. vulvaria L.; 2; T; SEU

Halimione portulacoides (L.) Aellen; 2; Ch; CIHO

Cichoriaceae

Cichorium intybus L.; 2; H; WISP

Scolymus hispanicus L.; 2; H; MED

Sonchus tenerrimus L.; 1, 2; T; MED

Convolvulaceae

Convolvulus arvensis L.; 2; G; WISP

Fabaceae

Lotus cytisoides L.; 1, 2; Ch; MED

Vicia angustifolia L. ssp. angustifolia; 1; T; EURO

Malvaceae

Lavatera arborea L.; 2; H; MED

Malva sylvestris L.; 1, 2; H; MED

Moraceae

Ficus carica L.; 2; P; MED

Polygonaceae

Polygonum aviculare L.; 1, 2; T; WISP

Portulacaceae

Portulaca oleracea L.; 1,2; T; WISP

Primulaceae

Anagallis arvensis L.; 2; T; WISP

Sol a naceae

Solanum nigrum L.; 1, 2; T; WISP

Urticaceae

Parietaria judaica L.; 1; H; SEU

Ta maricaceae

Tamarix dalmatica Baumg.; 2; P; MED 


\section{MONOCOTYLEDONES}

\section{Amaryllidaceae}

Allium commutatum Guss.; 1, 2; G; MED

\section{Asparagaceae}

Asparagus acutifolius L.; 1; G; MED

\section{Poaceae}

Avena barbata Pott ex Link; 2; T; SEU

Cynodon dactylon (L.) Pers.; 1, 2; G; WISP

Dactylis glomerata L. ssp. hispanica (Roth) Nyman; 2; H; MED

Digitaria sanguinalis (L.) Scop.; 2; T; WISP

Elymus pycnanthus (Godr.) Melderis; 1, 2; G; MED; NT

Hordeum murinum L. ssp. leporinum (Link) Arcang.; 1, 2; T; MED

Parapholis incurva (L.) C.E.Hubb.; 2; T; MED; VU; spr

\section{Zosteraceae}

Posidonia oceanica (L.) Delile; 1, 2; Hy; MED; spr

\section{Analysis of the flora}

There are 39 taxa within 37 genera and 21 families. Among them, 35 and 24 taxa were found on Veliki Lagan and Mali Lagan, respectively (Tab. 1).

Tab. 1. Taxonomic analysis of the flora

\begin{tabular}{|l|c|c|c|}
\hline \multirow{2}{*}{ Taxa } & \multicolumn{2}{|c|}{ Angiospermae } & \multirow{2}{*}{ Total } \\
\cline { 2 - 4 } & Dicotyledones & Monocotyledones & 21 \\
\hline Families & 17 & 4 & 37 \\
\hline Genera & 27 & 10 & 32 \\
\hline Species & 24 & 8 & 7 \\
\hline Subspecies & 5 & 2 & 39 \\
\hline Species \& subspecies & 29 & 10 & 100.00 \\
\hline$\%$ & 74.4 & 25.6 & \\
\hline
\end{tabular}

Dicotyledones (74.4\% of the total flora) dominated monocotyledones (25.6\%). No Pteridophytes and Gymnospermae were recorded. The largest number of taxa belonged to the Chenopodiaceae and Poaceae (with seven taxa in each), followed by Cichoriaceae (3) and other families represented by two or only one taxon.

A relatively low number of taxa is to be expected due to the small surface area of the islets, low habitat diversity and the little human influence. The whole area of these islets is exposed to waves and strong salt spray due to the low altitudes ( $2 \mathrm{~m}$ a.s.l.). Therefore, halophytes and highly salt-tolerant taxa are the most common on both islets. In spring, 


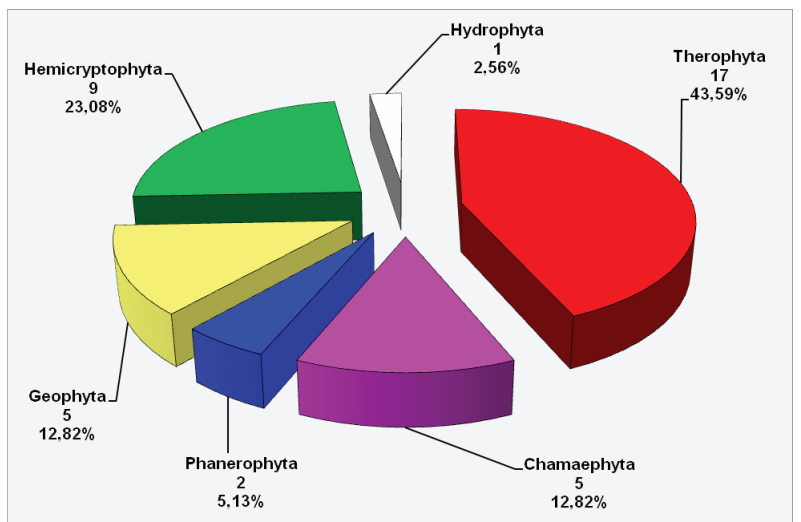

Fig. 2. Life form spectrum of the flora of Mali Lagan and Veliki Lagan.

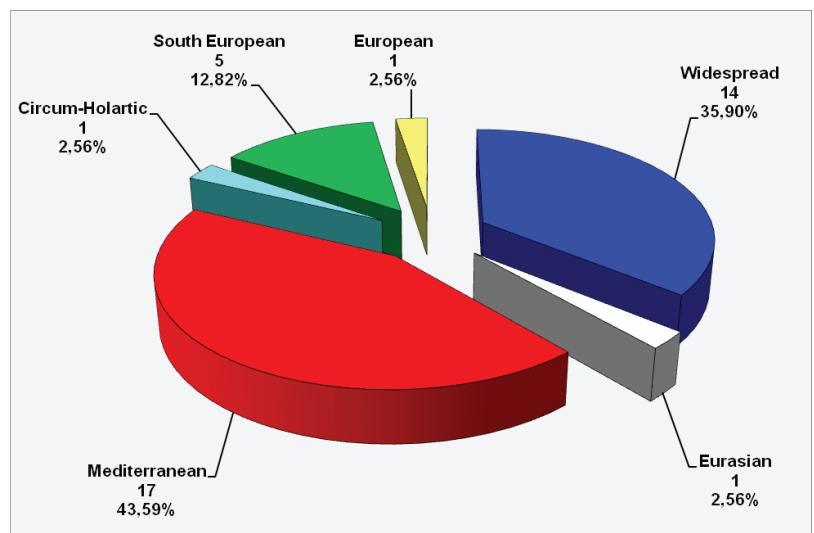

Fig. 3. The spectrum of floral elements in the study islets.

sea-gulls nest, fertilizing the soil and preserving some nitrophilic species such as Amaranthus retroflexus, Chenopodium strictum, Ch. vulvaria, Lavatera arborea, Solanum nigrum, etc.

Therophytes (43.59\%) prevailed, followed by hemicryptophytes (23.08\%), chamaephytes and geophytes (each of them with 18.52\%) (Fig. 2). In this study, compared to the results of PANDžA \& Milović (2013), the flora of the Veliki and Mali Lagan islets had a low contribution of phanerophytes (5.13\% vs. $12.91 \%)$. This can be explained by the saline environment, which is not suitable for these plants.

Most of the taxa belong to the Mediterranean chorological type (43.59\%) (Fig. 3). They are followed by widespread plants $(35.90 \%)$ and the South-European plants $(12.82 \%)$. In this case, compared to data given by us for Veli Rat (PANDžA \& Milović, 2013), the number of widespread plants is significantly higher (35.90\% vs $18.99 \%)$, while the contribution of the Southern European and Eurasian were lower. The spectrum of floral elements of the islets studied has no cultivated and adventitious plants, which is not unexpected due to the absence of anthropogenic influence and appropriate habitats. 
One endemic species (Carduus micropterus ssp. micropterus) was recorded in the flora of the two islets. There were also two species from the list of strictly protected species (Parapholis incurva and Posidonia oceanica) and one endangered species (Parapholis incurva-VU), one near threatened (Elymus pycnanthus - NT). Large populations of Posidonia oceanica were found in the sea around both of the islets which indicates well-preserved marine habitats.

\section{CONCLUSION}

As the vascular flora of the Veliki and Mali Lagan islets has not been researched before, all of the species presented in this paper are the very first findings for these islets. The present work and similar works to follow will help in the protection of the flora and increase the importance of conservation status for these sensitive ecological gems.

\section{ACKNOWLEDGEMENTS}

Acknowledgements to Mrs Eva Dušević for providing transportation to the islets as well as Mr Ljubo Mirković for giving as details on the islets' past. Thanks are also extended to two anonymous reviewers for their constructive comments on an earlier version of this manuscript.

Received September 19, 2014

\section{REFERENCES}

AnONymous, 2013a: Zakon o zaštiti prirode. NN 80/2013.

Anonymous, 2013b: Pravilnik o strogo zaštićenim vrstama. NN 144/2013, Prilog I.

Horvatić, S., 1963: Vegetacijska karta otoka Paga s općim pregledom vegetacijskih jedinica hrvatskog primorja. Prir. istraž. ser. Acta biol. 4(33), 5-181.

Horvatić, S., Ilijanić, Lj. \& LJ. Marković-Gospodarić, 1967-1968: Biljni pokrov okolice Senja. Senjski zbornik 3, 298 - 322.

NiкоLIĆ, T. (ed.), 2014a: Flora Croatica baza podataka / Flora Croatica Database. On-Line URL: http:// hirc.botanic.hr/fcd/. Botanički zavod, Prirodoslovno-matematički fakultet, Sveučilište u Zagrebu [last accessed on November 20, 2014].

Nikolić, T. (ed.), 2014b: Crvena knjiga vaskularne flore Hrvatske / Red Data Book of Vascular Flora of Croatia. On-Line URL: http://hirc.botanic.hr/fcd/CrvenaKnjiga/. Botanički zavod s Botaničkim vrtom, Prirodoslovno-matematički fakultet, Sveučilište u Zagrebu [last acessed on November 20, 2014].

Niкоцić T. \& J. Topić (ed.), 2005: Crvena knjiga vaskularne flore Republike Hrvatske. Kategorije EX, RE, CR, EN i VU. Ministarstvo kulture, Državni zavod za zaštitu prirode, Zagreb, 4-695.

Nikolić, T., Milović, M., Bogdanović, S. \& N. Jasprica, 2015: Endemi u hrvatskoj flori. Alfa d.d., Zagreb.

PAndžA, M. \& M. Milović, 2013: Flora i vegetacija na području Velog Rata (Dugi otok). In: Uglešıć, A. \& J. FARIČIć (ed.): Veli Rat, Zadar, 93-127.

Pignatti, S., 1982: Flora d'Italia. I-III. Edagricole. Bologna.

Raunkiær, C., 1934: The Life Forms of Plants and Statistical Plant Geography, being the collected papers of C. Raunkiær. Oxford University Press, Oxford. 


\section{SAŽETAK}

\section{Flora otočića Velikog i Malog Lagana (Dugi otok, Hrvatska)}

\section{Pandža \& M. Milović}

Flora otočića Velikog i Malog Lagana, koji se nalaze u sastavu značajnog krajobraza "Veli rat" na Dugom otoku, istraživana je tijekom 2014. Zabilježeno je 39 svojti vaskularnih biljaka iz 37 rodova i 21 porodice. Na Malom Laganu zabilježene su 24, a na Velikom Laganu 35 svojta. Porodice s najvećim brojem svojta su Chenopodiaceae i Poaceae (u svakoj sedam svojta). Analiza životnih oblika ukazuje na dominaciju terofita (17 svojta; 43,59\%), a fitogeografska analiza dominaciju biljaka mediteranske rasprostranjenosti (17 svojta; $43.59 \%$ ) od kojih su 10 općemediteranske biljke. Uz mediteranske svojte veliki je udio biljaka široke rasprostranjenosti (14 svojta; 35,90\%). Utvrđena je jedna endemična svojta (Carduus micropterus ssp. micropterus), jedna ugrožena (Parapholis incurva - VU), jedna gotovo ugrožena (Elymus pycnanthus - NT) te dvije strogo zaštićene svojte (Parapholis incurva i Posidonia oceanica). 